\title{
Management Students' Attitudes Toward Business Ethics: A Comparison Between France and Romania
}

\author{
Daniel Bageac \\ Olivier Furrer \\ Emmanuelle Reynaud
}

\begin{abstract}
This study focuses on the differences in the perception of business ethics across two groups of management students from France and Romania $(n=220)$. Data was collected via the ATBEQ to measure preferences for three business philosophies: Machiavellianism, Social Darwinism, and Moral Objectivism. The results show that Romanian students present more favorable attitudes toward Machiavellianism than French students; whereas, French students valued Social Darwinism and Moral Objectivism more highly. For Machiavellianism and Moral Objectivism the results are consistent with the literature and our hypotheses. However, contrary to our expectations, we find that Social Darwinism is more important in France than Romania. The results indicate that religious practice does not influence preferences for the three business philosophies. In terms of gender differences, women have less favorable attitudes toward Machiavellianism and more favorable attitudes toward Moral Objectivism than men.
\end{abstract}

KEY WORDS: ATBEQ, attitude toward business ethics, business ethics, France, Romania

\section{Introduction}

From a theoretical point of view, business ethics have appeared for only a few decades as a standalone field in management sciences (De George, 1987), to become "one of the most important research directions for international business" (Cardy and Servarajan, 2006; Phau and Kea, 2007). A better understanding of this evolution can be gained by integrating business ethics into a broader framework of an accelerating economic globalization. The integration of ethics is creating visible challenges, for which the traditional economic approach appears limited in the solutions it offers. Sims and Gegez
(2004) insist on the need for such integration; arguing that the convergence of diverse business practices, originating from different cultures, could potentially lead to problems and conflicts. This trend of global integration can be seen as the catalyst for the need of a deeper comprehension of the different business practices of actors belonging to different cultural contexts. Another important aspect of business ethics in the context of globalization is represented by expectations toward "responsible" or "ethical" behavior, despite the existence of different cultural and societal standards. Thus, Hofstede and Hofstede (2005) note that some business practices, such as the preferential employment of relatives, may be the norm in some cultures but unacceptable in other cultures.

Cross-cultural studies are critical to understand the differences in the perceptions of business ethics in different countries. For almost two decades several studies have developed a deeper understanding of the way people consider such a complex phenomenon as business ethics using the Attitudes Toward Business Ethics Questionnaire (ATBEQ) (Neumann and Reichel, 1987). Preble and Reichel (1988) studied differences in attitudes toward business ethics between American and Israeli students. Later, Small (1992) added a sample of students from Western Australia and Moore and Radloff (1996) extended the study by including a South African sample. More recently, Sims and Gegez (2004) added a Turkish sample and conducted a comparison across these five countries. Despite the contribution of European countries to the debate about business ethics (Crane and Matten, 2007), the ATBEQ has never been used to assess the attitudes toward business ethics in Europe. 
The present study seeks to reduce this gap by collecting data from two different European countries: France and Romania. It is a replication of the previous studies on the perception of business ethics by management students in two countries that have not yet been studied. As the previous studies have shown significant differences across countries from different continents, the objective of our study is to assess if there are also significant differences within Europe. The two European countries we are studying, France and Romania, share the same European cultural heritage but are different in several respects, which might influence people's attitude toward business ethics. France is a historical member of the European Union (EU) and a Western European country with a capitalist business environment, whereas Romania is a new member of the EU and an Eastern European country with a communist past.

The present study is not only a replication in new countries; it is also an extension. Whereas, the previous studies using the ATBEQ (Moore and Radloff, 1996; Preble and Reichel, 1988; Sims and Gegez, 2004; Small, 1992) were exploratory and descriptive in nature looking at country differences at the item level, we take a more theory testing and confirmatory approach by assessing country differences at the business philosophy level and by developing hypotheses about the expected directions of the country differences. Neumann (1987) initially developed the ATBEQ to assess people's adhesion to several business philosophies defined by Stevens (1979). However, with the exception of the study by Etheredge (1999), previous studies did not combine the questionnaire items to develop measures of these philosophies and only compared differences item by item. Moreover, whereas previous studies hypothesized differences at country level, we develop hypotheses at the societal- and individual levels to explain the differences between French and Romanian students in their attitudes toward three business ethic philosophies: Social Darwinism, Machiavellianism, and Moral Objectivism. In doing so, we are contributing to the development of the field of business ethics.

The rest of the article is organized as follows: we first examine business ethics from a strategic of point of view and present the major business ethical philosophies. Then we highlight the possible factors influencing cross-national differences at the national and individual levels and develop our hypotheses. In the next section, we describe the empirical study used to test the hypotheses and present the results. We end the article with a discussion and interpretation of the results and a conclusion describing the limitation of our study and directions for further research.

\section{Literature review}

Business ethics: a strategic issue

In the 1970s, when business ethics began to enter the public debate, the position of Friedman (1970), regarding the social responsibility of business, generated a lively debate concerning the status of ethics in business. The main issue in the debate was: Are business and ethics incompatible in nature, or is their association something natural, which can be beneficial for the entire economic system? Various (economic, social, institutional, and political) developments have since gone beyond the view of a conflict between ethics and business and have moved the discussion toward a more conciliatory understanding of the relationship between business and ethics (Hart, 2009). Hoffman and Moore (1984) suggest that the reason for this change in the business ethics debate is the increasing awareness that business is "a fabric of human relationships," which should not only be defined by economic interests but also by the necessity of moral regulations that are essential to survival.

Before discussing the relationships between business ethics and strategy, we need to provide a definition of what business ethics is. Following Crane and Matten (2007, p. 5), we define business ethics as the study of business situations, activities, and decisions where issues of right and wrong are addressed. This definition is relatively similar to the definition suggested by Carroll and Buchholtz (2008, p. 242) stating that: "business ethics is concerned with good and bad or right and wrong behavior and practices that take place within a business context." As it stands out from the later definition, the issues of both good and bad and right and wrong are at the heart of business ethics, despite the fact that they come from different disciplines: morals (right and wrong) and ethics (good and bad). To deal with this aspect, we 
adopt Carroll and Buchholtz' (2008, p. 242) perspective and consider ethics and morality "as being so similar to one another that we may use the terms interchangeably to refer to the study of fairness, justice, and right and wrong behavior in business."

Commercial influences, such as one vendor's slogan of "Ethics pays!", summarize the relationship between ethics and strategy. With regard to this relationship, we first observe that business ethics supports the legitimacy of a firm's strategic behavior. It is ethics that ensure society's acceptance of the business's "right to produce" or "license to operate." Similarly, Carroll (1979) argues that one of the first social responsibilities of a firm is economic and is concerned with a firm's financial performance. A firm that is not making a profit will quickly be out of business. However, Suchman (1995) also suggests that acting ethically is also a necessary condition for a firm to stay in business. When a firm's behavior is perceived as unethical or inappropriate within the system of values of a particular society, the firm and its products and services are likely to be rejected as illegitimate, endangering the survival of the firm (Waddock et al., 2002). Legitimacy is an important issue linking ethics and strategy. Indeed, the lack of ethics can be particularly costly for a firm (Suchman, 1995).

However, recent literature has begun to demonstrate the relativism of ethical standards across countries. For example, political corruption, which has a strong impact on business strategies (Habib and Zurawicki, 2002; Meschi, 2009), is often perceived differently in different countries and cultures (Davis and Ruhe, 2003; Getz and Volkema, 2001; Husted, 1999; Martin et al., 2007). This is due to the presence of different conceptions of business ethics based on different philosophies (Stevens, 1979).

\section{Major business philosophies}

In his 1979 seminal book, Stevens identified and defined nine business philosophies from which three can be retrieved by the ATBEQ survey: Social Darwinism, Machiavellianism, and Moral Objectivism. ${ }^{1}$

Developed by Herbert Spencer, Social Darwinism is the combination of Charles Dawin's theory of evolution and natural selection and Adam Smith's "invisible hand" (Miesing and Preble, 1985). Social
Darwinism is essentially a utilitarian philosophy, which argues that individuals should freely pursue their self-interest in a competitive environment. In such an environment, social welfare is created as the strong and the fittest survive and the inefficient are eliminated. The idea of progress is an essential idea of Social Darwinism. While natural selection is a key element of progress for the biological world, natural selection in the business world is made possible through free market mechanisms. Social Darwinism is also an amoral philosophy, which argues that morality has no place in a business world governed by natural laws (Miesing and Preble, 1985). The business world, just as the social or biological realm, is characterized by continuous evolution. Social Darwinism is the most prevalent philosophy in business ethics (Neumann, 1987).

Machiavellianism pertains to a business philosophy, which considers that a business firm is a selfcontained organism with its own "natural" laws that can be bent but not broken and that efficiency should take precedence over virtue to succeed (Miesing and Preble, 1985). Machiavellianism refers to the fact that we judge an action - in the sense of ethics - not on the basis of the conformity of this action to any categorical imperative, but to the efficient achievement of its goal. Machiavellianism promotes a business philosophy based on what is real, rejecting idealism: "people should believe in what they do instead of doing what they believe in" (Christie and Geis, 1970). Machiavellianism is also an amoral philosophy as the end, which is usually winning, is a sufficient justification for the means (Miesing and Preble, 1985).

Moral Objectivism focuses on the ability to reason within the existing reality: rational action is the only conformity to reality, the most productive, and the only approach worthy of being called ethical. Similar to Machiavellianism, Moral Objectivism is rational self-interest; however, contrarily to Machiavellianism, Moral Objectivism does not consider the real world to be at odds with ethics (Miesing and Preble, 1985). According to Moral Objectivism, an individual's moral obligation is to achieve their own well-being but in order to achieve it, they ought to have a moral code, a sort of meta-ethic, valid for everyone. Therefore, following such a moral code is necessary for individuals to succeed and reach their personal goals. 
Table I shows the ATBEQ items developed to measure each type of business philosophy expressed.

\section{International differences in attitudes toward business ethics}

We are often tempted to consider that the globalization of trade, financial transactions, and technology is accompanied in equal measure by a globalization of culture. Indeed, the global distribution of certain clothing or fast food brands partly homogenizes consumption patterns (Levitt, 1983), but important differences still persist (Hofstede and Hofstede, 2005).

\section{The societal variables (the national context)}

Several societal variables can be identified from the literature to explain differences in preferences for business philosophies. The wealth of the country is one of the most commonly mentioned factors. According to Inglehart (1997), the level of economic development is critical to explain differences in ethical values. Altruistic values (also termed "postmaterialist") are most often observed in wealthy societies, and seem to show that charity only happens on a superfluous level, not by necessity. In contrast, the pursuit of one's self-interest remains the prerogative of the least developed countries (Inglehart, 1997). In advanced industrial economies, high levels of economic security, technological development, and education result in the adoption of post-materialist values that emphasize subjective well-being, self-expression, quality of life, as well as concern for the environment and others. Inglehart and Baker (2000) confirmed that individuals in high GNP per capita countries were more likely to adhere to post-materialist values whereas individuals in low GNP per capita countries were more likely to support traditional and self-interested values. Even among developed European countries, we can observe a significant relationship between a country's GDP and altruistic values (Reynaud et al., 2007). In addition, economic development level is negatively related to corruption and the acceptability of unethical practices (Getz and Volkema, 2001; Husted, 1999).
A second societal variable often used to explain international differences in ethical values is economic growth. In countries with economic growth, individuals are likely to be more concerned with their personal economic self-interest; whereas, in countries with a stable economic situation, individuals are likely to have adapted to their business philosophy and other considerations may be relatively more salient than their personal material resources (Kemmelmeier et al., 2002; Mauro, 1995). For example, Kemmelmeier and colleagues (2002) argue that in countries where economic conditions are deteriorating, there is greater concern for personal economic well-being than with the natural environment. This higher emphasis on economic self-interest is consistent with Mauro's (1995) finding that corruption is negatively related to economic growth. Reynaud and colleagues (2008) also found that in Europe, respondents in countries with the lowest level of economic growth attributed the highest importance to both environmental and social responsibility.

A body of research also focuses on political ideology in order to better understand international differences. Two economic ideologies appear to be in conflict. Capitalism, which involves a specific understanding of ethics, focuses on the pursuit of an individual's self-interest. Socialism accents the group's interests over those of its individual members. Indeed, the adoption of a capitalist ideology in former socialist countries has led, a generation later, to the same self-interested values (England and Lee, 1974).

As previously mentioned, an important factor influencing international differences in business ethics is corruption. For example, the results of Grimes' (2004) study shows significant differences in the level of cheating among students from Central Europe in contrast to their American counterparts. Spicer and colleagues (2004) also note that American expatriate managers in Russia are more lenient regarding some questionable ethical behavior (e.g., bribes) in their relationships with governmental authorities. Wated and Sanchez (2005) show a significant tolerance to corruption among Ecuadorian managers.

In sum, high GDP, growth rate, and low corruption lead to higher levels of pro-social and lower levels of self-interested ethics. Table II summarizes these societal variable indicators for France and 


\section{TABLE I}

ATBEQ items and the correspondent business philosophies

\section{ATBEQ items}

1. The only moral of business is making money (Machiavellianism^)

2. A person who is doing well in business does not have to worry about moral problems (Machiavellianism^)

3. Every business person acts according to moral principles, whether he/she is aware of it or not (Moral Objectivism)

4. Act according to the law, and you cannot go wrong morally (Legalism^)

5. Ethics in business is basically an adjustment between expectations and the way people behave (Ethical Relativism ${ }^{\star}$ )

6. Business decisions involve a realistic economic attitude and not a moral philosophy (Machiavellianism)

7. Moral values are irrelevant to the business world (Machiavellianism^)

8. The lack of public confidence in the ethics of business people is not justified (Ethical Relativism)

9. "Business ethics" is a concept for public relations only (Machiavellianism^)

10. The business world today is not different from what it used to be in the past. There is nothing new under the sun (Ethical Relativism*)

11. Competitiveness and profitability are independent values (exist on their own) (Social Darwinism)

12. Conditions of a free economy will serve best the needs of society. Limiting competition can only hurt society and actually violates basic natural laws (Social Darwinism)

13. As a consumer when making an auto insurance claim, I try to get as much as possible regardless of the extent of the damage (Social Darwinism)

14. While shopping at the supermarket, it is appropriate to switch price tags or packages (Social Darwinism)

15. As an employee, I take office supplies home; it does not hurt anyone (Social Darwinism)

16. I view sick days as vacation days that I deserve (Social Darwinism)

17. Employee wages should be determined according to the laws of supply and demand (Social Darwinism)

18. The main interest of shareholders is maximum return on their investment (Social Darwinism)

19. George X says of himself, "I work long, hard hours and do a good job, but it seems to me that other people are progressing faster. But I know my efforts will pay off in the end." Yes, George works hard, but he's not realistic

(Machiavellianism)

20. For every decision in business the only question I ask is, "Will it be profitable?" If yes - I will act accordingly; if not, it is irrelevant and a waste of time (Machiavellianism)

21. In my grocery store every week I raise the price of a certain product and mark it "on sale." There is nothing wrong with doing this (Machiavellianism)

22. A business person cannot afford to get hung up on ideals (Machiavellianism)

23. If you want a specific goal, you have got to take the necessary means to achieve it (Machiavellianism)

24. The business world has its own rules (Machiavellianism)

25. A good business person is a successful business person (Machiavellianism)

26. I would rather have truth and personal responsibility than unconditional love and belongingness (Moral Objectivism)

27. True morality is first and foremost self-interested (Moral Objectivism)

28. Self-sacrifice is immoral (Moral Objectivism)

29. You can judge a person according to his work and his dedication (Moral Objectivism)

30. You should not consume more than you produce (Moral Objectivism)

Note: The items marked by a star $\left(^{\star}\right)$ are not present in Stevens' 1979 book. Their integration in a specific business philosophy follows our own interpretation.

Romania. Therefore, French business students are more likely to value business philosophies based on moral interests and Romanian business students are more likely to value business philosophies based on amoral self-interest. Thus, we propose the following hypotheses:
Hypothesis 1a: French business students value Moral Objectivism in business ethics more than Romanian business students.

Hypothesis 1b: Romanian business students value Machiavellianism in business ethics more than French business students. 
TABLE II

The societal variables indicators

\begin{tabular}{|c|c|c|c|}
\hline Indicator & Source & France & Romania \\
\hline $\begin{array}{l}\text { Corruption ( } 2000-2008 \text { mean. A higher } \\
\text { score indicates a less corrupt country) }\end{array}$ & $\begin{array}{l}\text { Transparency International } \\
\text { (http://www.transparency.org) }\end{array}$ & 7.18 & 3.21 \\
\hline GDP/capita (2000-2007 mean, in U.S. \$) & $\begin{array}{l}\text { United Nations Statistics Division } \\
\text { (http://unstats.un.org) }\end{array}$ & $29^{\prime} 889.67$ & $3^{\prime} 697.64$ \\
\hline $\begin{array}{l}\text { GDP/capita growth rate } \\
(2000-2007 \text { average, in \%) }\end{array}$ & Eurostat (http://epp.eurostat.ec.europa.eu) & 1.41 & 6.21 \\
\hline
\end{tabular}

Hypothesis 1c: Romanian business students value Social Darwinism in business ethics more than French business students.

\section{The individual-level variables}

Individuals' ethical values and preferences for business philosophies are not only influenced by cultural and institutional factors, but also by their personal characteristics (Furrer et al., 2010; Ralston et al., 2009). Therefore, we also investigate the effect of two important individual-level factors: religious practice and gender on students' attitudes toward business ethics (Kidwell et al. 1987; Schwartz and Huismans, 1995).

The first individual-related variable relates to a religious dimension. Religion plays an important role in the constitution of business ethics. As Melé (2000, p. 11) highlights, "theology offers reasons to act in a proper way, bringing an additional motivation to those based on philosophical aspects." In the Christian world "the doctrine of the Church has also inspired many practices shaping a paternalistic model of management that can be seen retrospectively as 'socially responsible"' (Acquier et al., 2005, p. 10). Ralston and colleagues (1997) even suggest that the impact of religion on ethical values is more important than political ideology. This is consistent with the fact that "religious leaders teach the importance of certain values and denigrate others" (Schwartz and Huismans, 1995, p. 88). However, Schwartz and Huismans (1995) show that all religions are similarly related to the same individual values. All religions promote the values of respect of others (Ibrahim et al., 2008; Schwartz and Huismans, 1995). It would therefore appear that the belief in a God, or the adhesion to a religion is more important when explaining the difference in ethical values than the religion itself (at least within the Judeo-Christian religions studied in the article, such as Judaism, Catholicism, Protestantism, and Orthodoxy). Within these Judeo-Christian religions no differences were observed in ethical behavior between religions, only the level of religious practice appeared to explain the differences in terms of ethical behavior (Schwartz and Huismans, 1995). Accordingly, religion practicing individuals are more likely to prefer moral business philosophies (i.e., Moral Objectivism) and nonpracticing students are likely to prefer amoral philosophies (i.e., Machiavellianism and Social Darwinism). We therefore propose the following hypotheses:

Hypothesis 2a: Religion practicing business students value Moral Objectivism in business ethics more than non-practicing business students.

Hypothesis 2b: Non-practicing business students value Machiavellianism in business ethics more than practicing business students.

Hypothesis 2c: Non-practicing business students value Social Darwinism in business ethics more than practicing business students.

With respect to gender, several studies highlight more ethical behavior among women than men. The study of Phau and Kea (2007) shows the superior value of ethics among female students of three countries studied (Australia, Hong Kong, and Singapore). Similar results were found in the work of Peterson and colleagues (2001). Empirical results are not always consistent. For example, Kidwell and colleagues (1997) find no significant differences between men and women concerning the reasons for their ethical behavior. However, the results of a meta-analysis by Borkowski and Ugras (1998) 
demonstrate that female students exhibit more positive ethical attitudes than males. Accordingly, we expect that women adopt more moral business ethics attitudes than men, who are more focused on their amoral self-interest. Thus, we hypothesize:

Hypothesis 3a: Female business students value Moral Objectivism in business ethics more than male business students.

Hypothesis 3b: Male business students value Machiavellianism in business ethics more than female business students.

Hypothesis 3c: Male business students value Social Darwinism in business ethics more than female business students.

\section{Method}

Subjects

To empirically test the hypotheses, we used a questionnaire survey. Data was collected from a sample of 220 business students (102 French and 118 Romanian students). As in the previous studies we are replicating (Moore and Radloff, 1996; Phau and Kea, 2007; Preble and Reichel, 1988; Sims and Gegez, 2004; Small, 1992), we used business students in order to insure the comparability of the results. Furthermore, the attitudes and values of business students are important in themselves, as these business students represent future managers (Preble and Reichel, 1988). Representing the future generation of managers, business students are an important group with strong potential impact on both the everyday practice of, and the principles governing, business (Glenn, 1992). All respondents were students from two different business schools (one in France and one in Romania). Descriptive statistics of the samples from the two countries are shown in Table III.

\section{Research instrument and measures}

The questionnaire was divided into two sections. In the first section, the attitudes of the respondents toward the three business philosophies were measured using the ATBEQ. We used the original version of the questionnaire developed by Neumann (1987),
TABLE III

Descriptive statistics of the population

\begin{tabular}{lcc}
\hline $\begin{array}{l}\text { Socio-demographic } \\
\text { characteristic }\end{array}$ & France & Romania \\
\hline $\begin{array}{l}\text { Gender } \\
\text { Male }\end{array}$ & $40(39.2 \%)$ & $26(22.0 \%)$ \\
Female & $62(60.7 \%)$ & $92(78.0 \%)$ \\
Age & & \\
$20-25$ & $88(86.2 \%)$ & $118(100 \%)$ \\
$26-30$ & $6(5.8 \%)$ & - \\
$31-35$ & $6(5.8 \%)$ & - \\
$36-40$ & $2(1.9 \%)$ & - \\
Religion & & \\
Catholic & $51(50 \%)$ & - \\
Protestant & $1(1 \%)$ & $1(0.8 \%)$ \\
Orthodox & $1(1 \%)$ & $112(94.9 \%)$ \\
Jew & $1(1 \%)$ & - \\
Muslim & $4(3.9 \%)$ & - \\
Other & $1(1 \%)$ & $1(0.8 \%)$ \\
None & $43(42.2 \%)$ & $4(3.4 \%)$ \\
Religion practice (all religions) & \\
Practicing & $6(5.9 \%)$ & $25(21.2 \%)$ \\
Occasionally practicing & $24(23.5 \%)$ & $65(55.1 \%)$ \\
Non-practicing & $72(70.5 \%)$ & $28(23.7 \%)$ \\
\hline
\end{tabular}

which is based on the Stevens (1979) "Value Clarification Exercises" (Small, 1992, p. 746). Permission to administer this survey was requested from Professor Arie Reichel, who kindly authorized its use. The ATBEQ consists of 30 items, which are measured on five-point Likert scales, ranging from 1 (totally disagree) to 5 (totally agree). In the second section of the questionnaire, we added items to measure demographic data, such as age, gender $(1=$ male, $2=$ female), religion, and the level of religious practice $(1=$ practicing, $2=$ occasionally practicing, $3=$ non-practicing). The survey was translated into French and Romanian. To ensure the quality of the translation, we used a double translation. In addition, the survey was pre-tested. The survey was selfadministered during class hours breaks.

Analysis

Previous studies of students' attitudes toward business ethics based on the ATBEQ (Moore and 
Radloff, 1996; Phau and Kea, 2007; Preble and Reichel, 1988; Sims and Gegez, 2004; Small, 1992) used rather unsophisticated and exploratory data analysis techniques. In general, they computed means and standard deviations of each item and used simple $t$ tests to compare results across countries at the item level. In the Appendix, we provide means and standard deviation for the 30 items to allow for comparison with previously published data.

Contrary to these previous studies, we used a confirmatory method. First, we used a combination of exploratory (EFA) and confirmatory (CFA) factor analyses to identify cross-culturally equivalent items to measure the three main business philosophies: Social Darwinism, Machiavellianism, and Moral Objectivism. Next, we computed a series of paired $t$ tests to assess the differences, within a country, in the ranking of business philosophies. Finally, to test the proposed hypotheses, we conducted a multiple analysis of variance (MANOVA), in which the three business philosophies were entered as dependent variables and country, gender, and level of religious practices were used as factors. We used MANOVA rather than independent $t$ tests because the three business philosophies are moderately correlated (Hair et al., 1998).

\section{Results}

Construct validity and cross-cultural invariance of the business philosophies

We first ran a series of EFA to identify the best items to measure the three business philosophies consistently across our two country samples because of the weak reliability of some of the ATBEQ items and the relatively small size of our samples (CFA requires at least 10 respondents per item in each country Byrne, 2001). We identified three items for Social Darwinism: item 13 ("As a consumer when making an auto insurance claim, I try to get as much as possible regardless of the extent of the damage"), 16 ("I view sick days as vacation days that I deserve"), and 18 ("The main interest of shareholders is maximum return on their investment"); three items for Machiavellianism: item 2 ("A person who is doing well in business does not have to worry about moral problems"), item 6 ("Business decisions involve a realistic economic attitude and not a moral philosophy"), and item 7 ("Moral values are irrelevant to the business world"); and finally two items for Moral Objectivism: item 26 ("I would rather have truth and personal responsibility than unconditional love and belongingness") and item 27 ("True morality is first and foremost self-interested"). The three scales have low but acceptable reliabilities ranging from 0.55 to 0.75 .

CFA was used to assess the configural, metric, and scalar invariance of the three business philosophy scales (Steenkamp and Baumgartner, 1998). The CFAs for the two country samples showed metric invariance for the three scales together and acceptable fit indices (RMSEA $=0.006[90 \%$ Confidence Interval 0.000-0.058], TLI $=0.997$; CFI $=0.998$ ) (Byrne, 2001). However, scalar invariance, which is necessary to pool the data and compare means, was not achieved (Byrne, 2001; Steenkamp and Baumgartner, 1998) (Fit indices: RMSEA $=0.075$ [90\% CI: 0.055-0.095], TLI $=0.544$; CFI $=0.658$ ). As scalar invariance was not attained in the CFA, we standardized scores for the three business philosophy scales to test the hypotheses (Sin et al., 1999). The resulting scores represent the relative importance of each business philosophy.

\section{Within country differences in ranking of business philosophies}

Paired-sample $t$ tests were conducted to assess within country differences in the relative importance of Social Darwinism, Machiavellianism, and Moral Objectivism (see Table IV). In the overall sample, across countries, Social Darwinism is perceived as relatively more important than both Moral Objectivism and Machiavellianism. However, there are differences between the ranking of the business philosophies for the French and Romanian students. The results show that for French business students, Social Darwinism is perceived to be relatively more important than Moral Objectivism, which in turn, is perceived to be relatively more important than Machiavellianism. On the contrary, for Romanian students, Machiavellianism and Social Darwinism are both perceived as relatively more important than Moral Objectivism. 
TABLE IV

Paired sample $t$ test differences among business philosophies

\begin{tabular}{|c|c|c|c|c|c|c|c|}
\hline & \multicolumn{2}{|c|}{$\begin{array}{l}\text { Social Darwinism } \\
\text { (DAR) }\end{array}$} & \multicolumn{2}{|c|}{$\begin{array}{c}\text { Machiavellianism } \\
\text { (MAC) }\end{array}$} & \multicolumn{2}{|c|}{$\begin{array}{c}\text { Moral Objectivism } \\
(\mathrm{OBJ})\end{array}$} & \multirow[t]{2}{*}{$t$ test (Diff. sig. at 5\%) } \\
\hline & Mean & $\mathrm{SD}$ & Mean & $\mathrm{SD}$ & Mean & $\mathrm{SD}$ & \\
\hline France & 0.43 & 0.66 & -0.36 & 0.79 & -0.06 & 0.80 & $\mathrm{MAC}<\mathrm{OBJ}<\mathrm{DAR}$ \\
\hline Romania & 0.16 & 0.75 & 0.22 & 0.76 & -0.38 & 0.82 & $\mathrm{OBJ}<(\mathrm{DAR}, \mathrm{MAC})$ \\
\hline Total & 0.29 & 0.72 & -0.05 & 0.83 & -0.23 & 0.82 & $(\mathrm{OBJ}, \mathrm{MAC})<\mathrm{DAR}$ \\
\hline
\end{tabular}

Hypotheses testing: between country differences in business philosophies

A MANOVA was conducted to test Hypotheses 1-3 regarding influences on the importance of Social Darwinism, Machiavellianism, and Moral Objectivism across countries. In the MANOVA, the dependent variables were the three business philosophy scale scores; the independent variables were country, gender, and religious practice. None of the interactions were significant, thus they were removed from the analysis for parsimony.

The MANOVA results show a significant effect for country (Wilks' $\Lambda=0.87, \quad F=16.39, p<$ 0.001 ) and for gender (Wilks' $\Lambda=0.97, F=3.32$, $p<0.05$ ), but not for religious practice (Wilks' $\Lambda=0.99, \quad F=0.40, p>0.04)$. The MANOVA results are reported in Table $\mathrm{V}$.

Hypothesis 1 proposed than French students would attribute relatively higher importance to Moral Objectivism (Hypothesis 1a), lower importance to Machiavellianism (Hypothesis 1b), and lower importance to Social Darwinism (Hypothesis 1c) than would Romanian students. There were significant country differences for Moral Objectivism $(F=11.25, p<0.001)$, Machiavellianism $(F=$ 32.93, $p<0.001)$, and Social Darwinism $(F=5.81$, $p<0.05)$. The results of the post-hoc group comparisons are shown in Table V. Consistent with Hypothesis 1c, students in France attribute more

TABLE V

MANCOVA and pairwise comparisons' results

\begin{tabular}{|c|c|c|c|c|}
\hline & Social Darwinism & Machiavellianism & Moral Objectivism & Wilks $\Lambda$ ( $F$ value $)$ \\
\hline \multicolumn{5}{|l|}{ Country } \\
\hline France $^{a}$ & 0.41 & -0.38 & -0.03 & \\
\hline Romania $^{a}$ & 0.15 & 0.30 & -0.45 & \\
\hline$F$ value & $5.81^{\star}$ & $32.93 \star \star \star$ & $11.25 \star \star \star$ & $0.87 \star \star \star(16.39)$ \\
\hline \multicolumn{5}{|l|}{ Gender } \\
\hline Male $^{a}$ & 0.27 & 0.10 & -0.37 & \\
\hline Female $^{\mathrm{a}}$ & 0.29 & -0.18 & -0.11 & \\
\hline$F$ value & 0.03 & $5.82^{\star}$ & $4.66^{\star}$ & $0.97 \star(3.32)$ \\
\hline \multicolumn{5}{|l|}{ Religious practice } \\
\hline Practicing $^{a}$ & 0.24 & -0.10 & -0.14 & \\
\hline Occasionally practicing $^{\mathrm{a}}$ & 0.32 & -0.07 & -0.26 & \\
\hline Non-practicing & 0.29 & 0.04 & -0.33 & \\
\hline$F$ value & 0.15 & 0.52 & 0.59 & $0.99(0.40)$ \\
\hline
\end{tabular}

${ }^{\mathrm{a}}$ Marginal means, ${ }^{\star} p<0.05,{ }^{\star \star}{ }_{p} p 0.01,{ }^{\star \star \star}{ }^{\star} p<0.001$. 
importance Moral Objectivism than students in Romania, and consistent with Hypothesis 1b, students in Romania attribute more importance to Machiavellianism than students in France. But inconsistent with hypothesis 1a, French business students attribute higher importance to Social Darwinism than Romanian business students. In sum, partial support for Hypothesis 1 is found.

Hypothesis 2 proposed that across countries, students who practice a religion more often would attribute higher importance to Moral Objectivism (Hypothesis 2a), lower importance to Machiavellianism (Hypothesis 2b), and lower importance to Social Darwinism (Hypothesis 2c) than students who practice a religion less often. Even if the results tend to support the hypotheses, none of the differences are statistically significant, thus providing no support for Hypothesis 2.

Finally, Hypothesis 3 proposed that across countries, male respondents would attribute lower importance to Moral Objectivism (Hypothesis 3a), higher importance to Machiavellianism (Hypothesis $3 \mathrm{~b}$ ), and higher importance to Social Darwinism (Hypothesis 3c) than female respondents would. There were significant gender differences for Machiavellianism $(F=5.82, p<0.05)$ and Moral Objectivism $(F=4.66, p<0.05)$, but not for Social Darwinism $(F=0.03, p>0.05)$. There is no gender difference related to Social Darwinism providing no support for Hypothesis 3c. However, consistent with Hypothesis 3b, male students across countries attribute more importance to Machiavellianism than female students. In addition, consistent with Hypothesis 3a, female students across countries attribute more importance to Moral Objectivism than male students. In sum, we find support for
Hypotheses 3a and 3b, but not 3c. Once again, business students react differently to Social Darwinism than the literature suggests.

\section{Discussion}

The first Hypothesis (1a) stating that French students valued Moral Objectivism in business ethics more than Romanian students and Hypothesis (1b), which stated that Romanian students valued Machiavellianism more than French students, have been fully supported (see Table VI). However, Hypothesis (1c), stating that Romanian students valued Social Darwinism more than French students, is rejected. Indeed, the reverse is shown: French business students value Social Darwinism in business ethics more than Romanian business students.

To explain this result, we build on the work of Iribarne (2006), which noted a high growth rate, capitalism and that a country's values are founded on many "mythical" reference points. Such myths have come into being due to different economic, political, and social events. The accelerated industrialization process, the need to eliminate the economic gap separating undeveloped countries from developed countries involves, in most cases, a sort of "oblivion" of certain traditional practices and values, as well as an unreserved adoption of new capitalistic values, such as competition and material success which is consistent with the preferences for Machiavellianism by Romanian students. Another explanation could be the significant corruption rate in Romania, which favors a Machiavellianism attitude. In contrast, the more pronounced focus on Moral Objectivism among French students could be

TABLE VI

Summary of finding for the hypotheses

\begin{tabular}{llll}
\hline Predictor variables & \multicolumn{1}{c}{ Countries } & Religion & Gender \\
\hline Hypotheses & 1 & 2 & 3 \\
a. Moral Objectivism & Supported $(0.001)$ & Not supported & Supported $(0.05)$ \\
b. Machiavellianism & Supported $(0.001)$ & Not supported & Supported $(0.05)$ \\
c. Social Darwinism & Not supported & Not supported & Not supported \\
\hline
\end{tabular}

For hypotheses $(\mathrm{H} 1 \mathrm{a}-\mathrm{c}, \mathrm{H} 2 \mathrm{a}-\mathrm{c}$, and $\mathrm{H} 3 \mathrm{a}-\mathrm{c})$ refer text. 
due, according to Iribarne (2006), to a specifically French historical and cultural context: the importance of professions. The creation of powerful professional groups is equivalent to the establishment of well-defined social groups, which have contributed to the creation of a strong social identity in France, an identity that cannot be easily challenged. This is the reason why French respondents like to use a meta-ethical framework, such as exists in Moral Objectivism, in their decision-making. This people-independent approach helps French people to be perceived as ethical and honest toward these groups.

The predominance of Social Darwinism among French business students could also be explained. The natural selection advanced by Darwin refers to competition between individuals for limited resources. The existence in France of an elitist education system based on selection could explain this finding. In France, top schools, called Grandes Ecoles, have highly selective admission procedures. Only 5\% of French students attend the Grandes Ecoles. Thus, students who succeed in such a competitive system are more likely to have internalized the idea of selection as a natural process and are, therefore, more likely to have positive attitudes toward Social Darwinism. If Social Darwinism is more valued among French business students than Romanian ones, it is nevertheless also important for the Romanian students. Social Darwinism is the preferred philosophy for the entire sample (see Table IV). This is consistent with Neumann (1987) for which Social Darwinism is the most prevalent philosophy in business ethics. This could be induced by business education in both countries.

The second hypothesis, related to the effect of religious practice, was rejected, even if the results tend to support the hypotheses. This could have been caused by an unbalance in the distribution of religious practice between the two country samples. In our data, most Romanian students (76.3\%) practice a religion, whereas most French students (70.5\%) are non-practicing. This may have created a confounding effect between country and religious practice. An alternative interpretation might take into account the specificity of the Romanian context, with its lower social and economic development over the past two decades. First, under pressure from the socialist regime, religious practice was relegated to the private sphere and suffered from strict state control (Conovici, 2006). This latently stored energy allowed religious practice to affirm itself with significant force within the public sphere at the beginning of the post-socialist transition period. Today, religion is a compulsory subject in the Romanian education system. In addition, the Romanian Orthodox Church (BOR) regained an important place in Romania's institutional landscape, creating strong social pressure favorable to religion and its important role in the socialization process of post-communist generations. This could explain the large percentage of Romanian students declaring themselves as practicing a religion. Besides this "religious" reality facet, there exists the socioeconomic aspect. The post-communist transition period has been described by Al-Khatib and colleagues (2004) as "[an] environment where everything is considered allowed 'unless expressly forbidden'... [and where]... ethics do not constitute a priority." This particular environment has probably resulted in the development of particular behavior with respect to business ethics more representative of Machiavellianism and Social Darwinism.

Hypothesis 3 stated that women valued Moral Objectivism more in business ethics, whereas men placed greater value on Machiavellianism and Social Darwinism. Our results show that the relationship between gender and the perception of business ethics is ambiguous. Indeed, female respondents are more favorable to Moral Objectivism than men and men are more favorable to Machiavellianism than female respondents. No differences were found concerning Social Darwinism. These results provide support for previous studies that highlight the differences between the ethical positions of men and women (e.g., Peterson et al., 2001). This is consistent with female and male values identified by Hofstede (Hofstede and Hofstede, 2005) at the national culture level. According to these cultural values, women are supposed to be more focused on a meta-ethic (e.g., Moral Objectivism) because they put an emphasis on groups and protection. Men are supposed to favor a more opportunist approach (e.g., Machiavellianism) to achieve competitive goals. This is consistent with our results. 
Concerning Social Darwinism, the interpretation of Phau and Kea (2007) is consistent with our findings. The results show that women and men have comparable levels in their perception of Social Darwinism, which could be due to the fact that the male and female students are both undergoing the same type of educational socialization. It should be noted that because of their age, their corresponding professional experience is very limited, thus making educational socialization the most important gateway to familiarity with the business world, which emphasizes, in general, Social Darwinism.

\section{Conclusion}

The present study has sought to broaden the understanding of attitudes toward business ethics within two generally unexplored countries: France and Romania. To study these attitudes, we used the ATBEQ survey, a well-known instrument used in various other studies (Moore and Radloff, 1996; Preble and Reichel, 1988; Sims and Gegez, 2004; Small, 1992). Survey data was collected from two groups of business students and allowed us to further explore the differences in relation to religious practice and gender.

With regards to the hypotheses, our results indicate that Romanian students responded more favorably than French students to Machiavellianism and less favorably to Moral Objectivism. This result can be interpreted in relation to the work of Iribarne (2006) and are also consistent with Inglehart's (2008) theory of intergenerational change. According to Inglehart, materialist values characterize individuals who have grown up in an economic context of scarcity, while post-materialist values are more specific to individuals who knew a much better standard of living during pre-adult socialization. Following this interpretation, the responses of Romanian students would focus on "materialist" values because their pre-adult socialization took place in a particular national context where living conditions were very difficult. To attain materialist security, they are more focused on the aims than on the means (principles of Machiavellianism). Concerning Social Darwinism, French business students valued more Social Darwinism than Romanian students. This could be explained by the elitist and selective education system in France (Grandes Ecoles), which is part of the French culture, and particularly important for students.

Regarding gender, our research shows that differences are supported for Machiavellianism and Moral Objectivism, but not for Social Darwinism. The differences are consistent with the findings of Peterson and colleagues (2001). Finally, the influence of religious practice is not significant. Given that the proportion of practicing students was significantly higher in the Romanian sample than in the French sample, we suggest this result may be either due to a confounding effect or in relation to the specificity of the Romanian context, where religion is more a matter of the private sphere, and the business sphere is more characterized by a multitude of values and practices. Alternatively, these non-significant results may have been influenced by our choice of business philosophies - Social Darwinism, Machiavellianism, and Moral Objectivism which are all three grounded in self-interest (Stevens, 1979), and as such may be incompatible with many religious approaches. Future research should investigate the effect of religious practices on alternative business ethical reasoning, such as Divine Commands and Theological Virtue, which are based on religious ethics rather than philosophical ethics (Goodchild, 1986).

A limitation of the present study concerns the characteristics of the sample of business students, which may be argued, is not representative of the larger populations of France and Romania. However, business students are future managers (Preble and Reichel, 1988) and therefore the values and attitudes are important because of their strong potential impact on both the everyday practice of and the principles governing business in the near future (Glenn, 1992). In addition, a student sample is fairly homogeneous to ease cross-country comparison and similar to the samples used in previous studies to provide comparative data (see Appendix). However, the absence of managerial experience may bias the results, as senior managers might have different attitudes. Therefore, future research may replicate our study with samples of managers to further assess the external validity of our results. 
Despite these limitations, this study provides implications for both organizations acting within the two cultural contexts, as well as for other international organizations in general. In this study, we emphasize the differences in the perceptions of business ethics of individuals from two countries when faced with similar situations or ethical dilemmas. These ethical dilemmas are common in the workplace and the choice of a resolution depends largely on the cultural background of the decisionmaker (Sims and Gegez, 2004). At the organizational level, this has a significant source of potential conflict that should be addressed with the utmost attention. Therefore, an understanding of ethics and business philosophies should be developed in any organization to promote the awareness of potential conflict and to allow management to adequately and transparently establish a clear set of institutional values through open dialog, as well as to demonstrate, train, and reward behavior consistent with these values. This becomes a necessity when dealing with the construction of a coherent global corporate culture (Ralston et al., 1993). One way that an international firm could achieve a global culture would be through the establishment of a universal corporate culture that would be capable of reconciling the values of various geographically dispersed employees and their different national cultures.

Our study also contributes to the development of the business ethics literature by testing hypotheses at the business philosophy level rather than at the item level. Contrary to previous studies using the ATBEQ, we worked at an aggregate level, which increases the validity of the study findings and allows us to test theoretically grounded hypotheses. In such, our study is a first step on the way to develop and improve scales to measure business philosophies (Etheredge, 1999). Future studies should further improve these scales and develop new ones to measure the other business philosophies identified by Stevens (1979).

\section{Note}

1 Among the ATBEQ items, only one measures Legalism and three items, with poor reliability, measure Ethical Relativism.

\section{Appendix}

TABLE A1

Descriptive statistics: French and Romanian respondents' attitudes toward business ethics

\begin{tabular}{|c|c|c|c|c|c|c|}
\hline \multirow[t]{2}{*}{ Item } & \multicolumn{2}{|c|}{$\begin{array}{c}\text { France } \\
(n=102)\end{array}$} & \multicolumn{2}{|c|}{$\begin{array}{l}\text { Romania } \\
(n=118)\end{array}$} & \multicolumn{2}{|c|}{$\begin{array}{c}\text { Total } \\
(n=220)\end{array}$} \\
\hline & Mean & SD & Mean & SD & Mean & $\mathrm{SD}$ \\
\hline 1 & 2.90 & 1.23 & 3.53 & 0.96 & 3.24 & 1.13 \\
\hline 2 & 1.75 & 0.82 & 3.42 & 1.16 & 2.65 & 1.31 \\
\hline 3 & 3.33 & 1.08 & 2.95 & 1.07 & 3.13 & 1.09 \\
\hline 4 & 2.25 & 0.94 & 1.78 & 0.42 & 2.00 & 0.74 \\
\hline 5 & 3.24 & 0.88 & 2.32 & 0.78 & 2.75 & 0.95 \\
\hline 6 & 3.07 & 1.07 & 3.82 & 0.88 & 3.47 & 1.04 \\
\hline 7 & 2.17 & 0.99 & 2.52 & 0.99 & 2.35 & 1.00 \\
\hline 8 & 3.23 & 0.98 & 2.90 & 0.97 & 3.05 & 0.99 \\
\hline 9 & 2.55 & 0.94 & 1.58 & 0.81 & 2.03 & 1.00 \\
\hline 10 & 2.55 & 1.17 & 2.25 & 1.15 & 2.39 & 1.17 \\
\hline 11 & 2.87 & 1.13 & 2.03 & 0.67 & 2.42 & 1.01 \\
\hline 12 & 3.17 & 1.10 & 3.72 & 1.04 & 3.46 & 1.10 \\
\hline 13 & 2.83 & 1.00 & 2.58 & 1.16 & 2.70 & 1.09 \\
\hline 14 & 1.68 & 0.97 & 1.36 & 0.70 & 1.51 & 0.85 \\
\hline 15 & 2.81 & 1.21 & 2.16 & 1.16 & 2.46 & 1.23 \\
\hline 16 & 1.59 & 0.80 & 2.73 & 1.15 & 2.20 & 1.15 \\
\hline 17 & 2.54 & 1.07 & 3.14 & 1.06 & 2.86 & 1.10 \\
\hline 18 & 4.03 & 0.94 & 4.26 & 0.66 & 4.15 & 0.81 \\
\hline 19 & 3.07 & 1.00 & 3.26 & 1.02 & 3.17 & 1.01 \\
\hline 20 & 3.06 & 1.20 & 3.52 & 1.08 & 3.30 & 1.16 \\
\hline 21 & 1.57 & 0.85 & 1.80 & 0.99 & 1.69 & 0.93 \\
\hline 22 & 2.32 & 1.00 & 2.68 & 0.97 & 2.51 & 1.00 \\
\hline 23 & 3.91 & 0.96 & 3.87 & 0.97 & 3.89 & 0.96 \\
\hline 24 & 3.61 & 0.96 & 3.89 & 0.95 & 3.76 & 0.96 \\
\hline 25 & 3.22 & 1.14 & 4.01 & 0.92 & 3.64 & 1.10 \\
\hline 26 & 2.54 & 1.03 & 3.00 & 1.21 & 2.79 & 1.15 \\
\hline 27 & 2.59 & 0.92 & 2.69 & 1.11 & 2.65 & 1.02 \\
\hline 28 & 2.65 & 0.99 & 2.59 & 1.02 & 2.62 & 1.00 \\
\hline 29 & 3.18 & 1.04 & 3.53 & 0.96 & 3.36 & 1.01 \\
\hline 30 & 3.22 & 1.07 & 3.42 & 1.16 & 3.33 & 1.12 \\
\hline Average & 2.78 & 1.14 & 2.91 & 1.22 & 2.85 & 1.18 \\
\hline
\end{tabular}

\section{References}

Acquier, A., J.-P. Gond and J. Igalens: 2005, 'Les fondements religieux de la responsabilité sociale de l'entreprise à la responsabilité sociale de l'entreprise comme religion', Cahier de recherche no. 2005-166, 
Centre de Recherche en Gestion, IAE de Toulouse, pp. 1-31. http://www.reims-ms.fr/agrh/docs/actesagrh/pdf-des-actes/2005acquier-gond-igalens002.pdf.

Al-Khatib, A. J., Ch. J. Robertson and D. N. Lascu: 2004, 'Post-Communist Consumer Ethics: The Case of Romania', Journal of Business Ethics 54, 81-95.

Borkowski, S. and Y. Ugras: 1998, 'Business Students and Ethics: A Meta-Analysis', Journal of Business Ethics 17(11), 1117-1127.

Byrne, B. M.: 2001, Structural Equation Modeling with AMOS: Basic Concepts, Applications, and Programming (Lawrence Erlbaum Associates, Malway).

Cardy, R. L. and T. T. Servarajan: 2006, 'Assessing Ethical Behavior: The Impact of Outcomes on Judgment Bias', Journal of Managerial Psychology 21(1), 52-72.

Carroll, A.: 1979, 'A Three-Dimensional Conceptual Model of Corporate Performance', Academy of Management Review 4(4), 497-505.

Carroll, A. B. and A. K. Buchholtz: 2008, Business and Society: Ethics and Stakeholder Management, 7th Edition (South-Western Cengage Learning, London).

Christie, R. and F. Geis: 1970, Studies in Machiavellianism (Academic Press, New York).

Conovici, I.: 2006, 'Biserica Ortodoxă Română în spatiul public postcomunist', Akademia 1(20), http://www. akademia.ro/articole.php?view $=261$.

Crane, A. and D. Matten: 2007, Business Ethics, 2nd Edition (Oxford University Press, Oxford).

Davis, J. H. and J. A. Ruhe: 2003, 'Perceptions of Country Corruption: Antecedents and Outcomes', Journal of Business Ethics 43(4), 275-288.

De George, R. T.: 1987, 'The Status of Business Ethics: Past and Future', Journal of Business Ethics 6(3), 201211.

England, G. W. and R. Lee: 1974, 'The Relationship Between Managerial Values and Managerial Success in the United States, Japan, India and Australia', Journal of Applied Psychology 59(4), 411-419.

Etheredge, J. M.: 1999, 'The Perceived Role of Ethics and Social Responsibility: An Alternative Scale', Journal of Business Ethics 18(1), 51-64.

Friedman, M.: 1970, 'The Social Responsibility of Business is to Increase its Profits', New York Times Magazine, 13 September, republished in W. Ch. Zimmerli, K. Richter and M. Holzinger (eds.): 2007, Corporate Ethics and Corporate Governance (Springer, Berlin/Heidelberg/New York), pp. 173-178.

Furrer, O., C. P. Egri, D. A. Ralston, W. Danis, E. Reynaud, I. Naoumova, M. Molteni, A. Starkus, F. L. Darder, M. Dabic and A. Furrer-Perrinjaquet: 2010, 'Attitudes Toward Corporate Responsibilities in Western Europe and in Central and East Europe', Management International Review 50(3), 379-398.
Getz, K. and R. Volkema: 2001, 'Culture, Perceived Corruption, and Economics', Business and Society 40(1), 7-30.

Glenn, J. R. Jr.: 1992, 'Can a Business and Society Course Affect the Ethical Judgment of Future Managers?', Journal of Business Ethics 11(3), 217-223.

Goodchild, L. F.: 1986, 'Toward a Foundational Normative Method in Business Ethics', Journal of Business Ethics 5(6), 485-499.

Grimes, P. W.: 2004, 'Dishonesty in Academics and Business: A Cross-Cultural Evaluation of Student Attitudes', Journal of Business Ethics 49(3), 273-290.

Habib, M. and L. Zurawicki: 2002, 'Corruption and Foreign Direct Investment', Journal of International business Studies 33(2), 291-307.

Hair, J. F. Jr., R. E. Anderson, R. L. Tatham and W. C. Black: 1998, Multivariate Data Analysis, 5th Edition (Prentice Hall, Upper Saddle River, NJ).

Hart, S.: 2009, 'Converging on Green', BizEd, JulyAugust, pp. 24-29.

Hoffman, W. M. and J. M. Moore: 1984, Business Ethics: Readings and Cases in Corporate Morality (McGraw-Hill, New York).

Hofstede, G. and G. J. Hofstede: 2005, Cultures and Organizations. Software of the Mind, 2nd Edition (McGraw-Hill, New York).

Husted, B. W.: 1999, 'Wealth, Culture, and Corruption', Journal of International Business Studies 30(2), 339-360.

Ibrahim, N. A., D. P. Howard and J. P. Angelidis: 2008, 'The Relationship Between Religiousness and Corporate Social Responsibility Orientation: Are There Differences Between Business Managers and Students?', Journal of Business Ethics 78(1-2), 165-174.

Inglehart, R.: 1997, Modernization and Postmodernization: Cultural, Economic, and Political Change in 43 Societies (Princeton University Press, Princeton, NJ).

Inglehart, R.: 2008, 'Changing Values Among Western Publics From 1970 to 2006', West European Politics 31(1-2), 130-146.

Inglehart, R. and W. E. Baker: 2000, 'Modernization, Cultural Change, and the Persistence of Traditional Values', American Sociological Review 65(1), 19-51.

Iribarne, Ph. d': 2006, L'Etrangeté française (Le Seuil, Paris).

Kemmelmeier, M., G. Krol and Y. H. Kim: 2002, 'Values, Economics, and Proenvironmental Attitudes in 22 Societies', Cross-Cultural Research 36(3), 256285.

Kidwell, J., R. Stevens and A. Bethke: 1987, 'Differences in the Ethical Perceptions Between Male and Female Managers: Myth or Reality', Journal of Business Ethics 6(6), 489-493. 
Levitt, T.: 1983, 'The Globalization of Markets', Harvard Business Review 61(3), 92-102.

Martin, K. D., J. B. Cullen, J. L. Johnson and K. P. Parboteeah: 2007, 'Deciding to Bribe: A Cross-Level Analysis of Firm and Home Country Influence on Bribery Activity', Academy of Management Journal 50(6), 1401-1422.

Mauro, P.: 1995, 'Corruption and Growth', Quarterly Journal of Economics 110(3), 681-712.

Melé, D.: 2000, 'Business Ethics from Christian Moral Theology: Perspectives Facing the 21st Century', http://www.iipe.org/resourcedocs/organisational. html.

Meschi, P.-X.: 2009, 'Government Corruption and Foreign Stakes in International Joint Ventures in Emerging Economies', Asia Pacific Journal of Management 26(2), 241-261.

Miesing, P. and J. F. Preble: 1985, 'A Comparison of Five Business Philosophies', Journal of Business Ethics 4(6), 465-476.

Moore, R. S. and S. E. Radloff: 1996, 'Attitudes Towards Business Ethics Held by South African Students', Journal of Business Ethics 15(8), 863-869.

Neumann, Y. and A. Reichel: 1987, The Development of Attitudes Toward Business Ethics Questionnaire (ATBEQ): Concepts, Dimensions, and Relations to Work Values. Working Paper, Department of Industrial Engineering and Management, Ben Gurion University of the Negev, Israel.

Peterson, D., A. Rhoads and B. C. Vaught: 2001, 'Ethical Beliefs of Business Professionals: A Study of Gender, Age and External Factors', Journal of Business Ethics 31(3), 225-232.

Phau, I. and G. Kea: 2007, 'Attitudes of University Students Toward Business Ethics: A Cross-National Investigation of Australia, Singapore and Hong Kong', Journal of Business Ethics 72(1), 61-75.

Preble, J. F. and A. Reichel: 1988, 'Attitudes Towards Business Ethics of Future Managers in the US and Israel', Journal of Business Ethics 7(12), 941-949.

Ralston, D. A., C. P. Egri, M. T. de la Garza Carranza and P. Ramburuth, et al.: 2009, 'Ethical Preferences for Influencing Superiors: A 41-Society Study', Journal of International Business Studies 40(6), 1022-1045.

Ralston, D. A., D. J. Gustafson, F. Cheung and R. H. Terpstra: 1993, 'Differences in Managerial values: A Study of U.S., Hong Kong and PRC Managers', Journal of International Business Studies 24, 249-275.

Ralston, D. A., D. H. Holt, R. H. Terpstra and K.-C. Yu: 1997, 'The Impact of National Culture and Economic Ideology on Managerial Work Values: A Study of the United States, Russia, Japan and China', Journal of International Business Studies 28(1), 177-207.
Reynaud, E., C. P. Egri, D. A. Ralston, W. Danis, A. Starkus, M. Dabic, F. Wangenheim, T. Dalgic, F. Castro, V. V. Potocan, M. Kavoossi, M. Molteni, I. Girson, D. Elenkov, J. Pla-Barber, I. Maignan, M. Weber and A. Wallace: 2007, 'The Differences in Values Between Managers of the European Founding Countries, the New Members and the Applicant Countries: Societal Orientation or Financial Orientation?', European Management Journal 25(2), 132-145.

Reynaud, E., C. P. Egri, D. A. Ralston, I. Palmer, H. Srinvasan, P. Fu, A. Butt, J. R. Gutierrez, W. Danis, C. L. Hoon, M. Yong-Lin, O. Furrer, J. Pla-Barber, M. Molteni, M. Dabic, H. B. Chia, C. Kuo, T. Casado, T. de la Garza, M. Richards, Y. Sidani, P. Hallinger and L. Milton: 2008 'Les déterminants du comportement responsable : une comparaison internationale à grande échelle', 17th AIMS Annual Congress, Nice Sophia Antipolis, May.

Schwartz, S. H. and S. Huismans: 1995, 'Value Priorities and Religiosity in Four Western Religions', Social Psychology Quarterly 58(2), 88-107.

Sims, R. L. and A. E. Gegez: 2004, 'Attitudes Towards Business Ethics: A Five Nation Comparative Study', Journal of Business Ethics 59(3), 253-265.

Sin, L. Y. M., G. W. E. Cheung and R. Lee: 1999, 'Methodology in Cross-Cultural Consumer Research: A Review and Critical Assessment', Journal of International Consumer Marketing 11(4), 75-96.

Small, M. W.: 1992, 'Attitudes Toward Business Ethics Held by Western Australian Students: A Comparative Study', Journal of Business Ethics 11(10), 745-752.

Spicer, A., T. W. Dunfee and W. J. Bailey: 2004, 'Does National Context Matter in Ethical Decision Making? An Empirical Test of Integrative Social Contracts Theory', Academy of Management Journal 47(4), 610620.

Steenkamp, J.-B. E. M. and H. Baumgartner: 1998, 'Assessing Measurement Invariance in Cross-National Consumer Research', Journal of Consumer Research 25(1), 78-90.

Stevens, E.: 1979, Business Ethics (Paulist Press, New York/Ramsey).

Suchman, M. C.: 1995, 'Managing Legitimacy: Strategic and Institutional Approaches', Academy of Management Journal 20(3), 571-610.

Waddock, S. A., C. Bodwell and S. B. Graves: 2002, 'Responsibility: The New Business Imperative', The Academy of Management Executive 16(2), 132-148.

Wated, G. U. and J. I. Sanchez: 2005, 'The Effects of Attitudes, Subjective Norms, Attributions, and Individualism-Collectivism on Managers' Responses to Bribery in Organizations: Evidence from a Developing Nation', Journal of Business Ethics 61(2), 111-127. 
Daniel Bageac and Emmanuelle Reynaud

Olivier Furrer CERGAM, IAE d'Aix-en-Provence, Aix Marseille University, Marseille, France E-mail:danielbageac@gmail.com Institute for Management Research, Radboud University Nijmegen, Nijmegen, The Netherlands 